\title{
Pendampingan Masyarakat Desa Kenongo dalam Peningkatan E-Business di Kabupaten Sidoarjo
}

\author{
Fitri Nur Latifah, Imam Fauji, Diah Krisnaningsih \\ Universitas Muhammadiyah Sidoarjo \\ fitri.latifah@umsida.ac.id,imamuna.114@gmail.com, \\ diah.krisnaningsih@gmil.com
}

\begin{abstract}
:
Today's technological developments have eliminated limitations and opened up various business opportunities that are assisted by the internet which is commonly called e-business. In e-business activities there are several positive and negative impacts. If seen from real activities, there are many positive impacts mentioned that are able to improve the performance of SME, facilitate business access, be more effective and efficient in daily economic activities. The negative impact that is often encountered in the field is prone to fraud and raises concerns in the community will make the business offline or the market will close down. This program aims to provide literacy to the public about sharia e-business and also socialization on how to apply $e$ business properly and wisely to avoid negative impacts. This program will provide literacy in the form of modules on e-business as well as socialization and assistance to SME and Kenongo villagers, especially housewives, whether they have businesses or not. It is hoped that Kenongo villagers will be able to have a good and wise understanding in applying e business in daily economic life as well as avoiding the negative impacts of e-business. So that through e-business can be an economic empowerment of citizens
\end{abstract}

Keyword: e-business, literacy, economic empowerment

\section{Pendahuluan}

Desa Kenongo adalah desa di kecamatan Tulangan kabupaten Sidoarjo terdapat dua dusun yakni dusun Kenongo dan dusun Ganting luas desa Kenongo kurang lebih 158,3 Ha(Latifah, Maika, \& Masruchin, 2017), Desa yang akhir-akhir ini perkembangan ekonominya sangat pesat dengan banyaknya pembangunan komplek perumahan baru dan munculnya berbagai bisnis rumahan atau UMKM pada masyarakat utamanya ibu rumah tangga. Sebagian ibu rumah tangga ini memiliki usaha dalam tujuan membantu perekonomian keluarga. Jenis usaha mereka antara lain laundry (cuci dan setrika baju), berjualan gorengan, membuka 
warung kopi sederhana, berjualan baju secara online maupun secara kredit, berjualan bubur, berjualan nasi kuning dan usaha membuka tempat kost.

Ibu rumah tangga ini awalnya adalah ibu rumah tangga biasa yang hanya sibuk mengurus keluarga dan anak-anaknya. Tetapi melihat banyaknya pendatang maka itu adalah peluag tersendiri untuk bisa menambah uang belanja keluarga tanpa harus keluar rumah jikapun masih harus keluar rumah tidak full day seperti pekerja pabrik atau kantoran. Sehingga ibu-ibu inilah yang kami bidik sebagai mitra dalam kegiatan ini. Tujuannya agar para ibu rumah tangga ini mendapatkan literasi yang baik tentang e-business dan mampu mengembangkan usahanya tersebut (Latifah, Maika, \& Ariyanti, 2019).

Dalam kegiatan ini kami mendapatkan pendanaan hibah Institusi Universitas Muhammadiyah Sidoarjo dengan skema PkaMI (Program kemitraan Masyarakat Institusi), kegiatan ini ditujukan kepada kemitraan masyarakat sebagai mitra dengan komponen : 1) Masyarakat yang produktif secara ekonomi; 2) Masyarakat yang belum produktif secara ekonomi, tetapi berhasrat kuat menjadi wirausahawan; 3) Masyarakat yang tidak produktif secara ekonomi (masyarakat umum/biasa).

Tujuan dari kegiatan PkaMI ini sendiri antara lain: 1) Membentuk dan mengembangkan kelompok masyarakat yang mandiri secara ekonomi dan sosial; 2) Membantu menciptakan ketentraman, dan kenyamanan lingkungan dalam kehidupan bermasyarakat; 3) Meningkatkan keterampilan berfikir, literasi atau ketrampilan lain yang dibutuhkan (softskill dan hardskill).

Pada observasi awal kami kepada mitra kami mendapatkan bahwa pemahaman mitra akan e-business belum begitu baik. Karena kurangnya pemahamana tersebut banyak yang belum berani mengaplikasikannya dalam kehidupan sehari-harinya dikarenakan banyaknya timbul kekhawatiran pada mitra seperti maraknya penipuan dalam bertransaksi menggunakan e-commerce maupun jual beli online seperti sudah melakukan proses transfer tetapi produk yang dipesan tidak dikirimkan, atau barang sudah terlanjur dikirimkan tetapi pembeli belum 
mentransfer uang. Ada kekawatiran juga tentang banyaknya berita negatif tentang pinjaman online (pinjol) dari beberapa fintech. Padahal disamping dampak-dampak negatif itu tentulah masih banyak dampak positif dari e-business yang bisa kita manfaatkan. Sebagai contoh : dalam pemasaran produk akan lebih efektif dan efisien, dalam saluran distribusi juga lebih cepat dalam investasi dengan menggunakan e-business masyarakat yang selama ini belum bisa terakses pembiayaannya oleh perbankan bisa menggunaan pembiayaan pada fintech dengan beberapa skema seperti peer to peer lending $(\mathrm{P} 2 \mathrm{P})$ yang syaratnya tidak serumit syarat kredit pada perbankan.(Maika \& Kautsar, 2019)

Sayangnya akses yang begitu besar pada e bisnis belum berkembang dengan baik secara nasional. Di Indonesia untuk fintech saja di Indonesia perkembangannya masih jauh tertinggal dengan negara lain seperti China, Hongkong dan India. Saat ini berdasarkan data yang dikeluarkan oleh perusahaan konsultan manajemen bisnis McKinsey \& Company dalam laporan terbarunya berjudul Digital Baking in Indonesia: Building Loyality and Generating Growth, tingkat penetrasi penggunaan layanan keuangan melalui fintech di Indonesia masih sekitar 5\%, angka ini jauh lebih rendah dibandingkan dengan negara China dengan presetasi 67\%, Hongkong 57\% dan India 39\%. Meskipun demikian, fintech di Indonesia tetap memiliki potensi besar untuk lebih berkembang kedepannya karena berdasarkan survei tahun 2017, pertumbuhan digitalisasi di Indonesia menjadi salah satu yeng tercepat di dunia, bahkan mengalahkan China dan Brazil (Wardhana, Mukminin, Syafira, Isnawati, \& Latifah, 2020).

Berdasarkan permasalahan tersebut sebagai salah satu bentuk tanggung jawab dosen dalam melaksanakan tridarma perguruan tinggi yaitu melakukan pengabdian pada masyarakat berupa sosialisasi dan pelatihan $e$-business bagi mitra diharapkan mitra mempunyai literasi yag baik tentang e-business dan mampu mengaplikasikannya dalam kehidupan sehari-hari sehingga bisa menjadikan pemberdayaan mitra dalam kegiatan ekonominya.(Perdani, Waziiroh, Deoranto, Perdani, \& Waziiroh, 2019) 
158 | Pendampingan Masyarakat Desa Kenongo dalam Peningkatan E-Business ...

\section{Metode}

Metode pelaksanaan yang dipakai dalam melaksanakan kegiatan PkaMI $e$ business desa Kenongo ini adalah:

1) Mengumpulkan data literasi tentang e-business (keunggulan dan dampak negatifnya);

Dalam kegiatan ini, tim kami melakukan studi literatur dengan menggunakan buku maupun jurnal-jurnal ilmiah yang sesuai dengan bidang pengabdian kami. Banyak sekali ditemukan data pada saat ini mengenai banyaknya kemajuan teknologi yang membuat perubahan besar dalam sekotor bisnis dan ekonomi, yakni makin maraknya transformasi bisnis menjadi e-business. Media online sangat besar pengaruhnya dalam perkembangan bisnis di era industrial 4.0 ini. Hampir semua orang mempunyai smartphone dan hampir semuanya pula mempunyai akun di media sosial.

Sehingga perkembangan teknologi ini pastinya juga sangat mempengaruhi perkembangan ekonomi dan bisnis, menjadi suatu keharusan adanya perubahan cara berbisnis di masyarakat juga yang menggunakan sentuhan teknologi bukan hanya di pasar nyata.

Ditambah pula saat tim kami melakukan kegiatan ini dipertengahan kegiata muncul wabah Covid 19, pemerintah mengeluarkan kebijakan tentang larangan keluar rumah dan jaga jarak dengan orang lain. Sehingga kebanyakan semua kegiatan apakah itu belajar, jual beli, berbisnis, diskusi semua dilakukan secara daring dari rumah masing-masing. Maka kegiatan literasi ini sangat bisa sangat bermanfaat bagi mitra kami.

2) Survei kepada mitra tentang pemahaman e-business (keunggulan dan dampak negatifnya);

Pada tahap ini kami menemukan bahwa mitra belum banyak yang memahami tentang apa itu bisnis online bahkan sebagian mitra merasa khawatir jika ingin bertransaksi secara online karena banyaknya 
pemberitaan banyak penipuan dan bahayanya bisnis melalui online.

Ketika kami menawarkan kepada para ibu rumah tangga desa Kenongo untuk sosialisasi dan pelatihan tentang e business mereka sangat antusias dan ingin sekali mengikutinya.

Bagi mereka pemahaman tentang e-business sudah merupakan keharsuan karena perkembanan tekologi dna mereka tidak ingin tertinggal informasi mengenai hal tersebut.

3) Pembuatan media sosialisasi dan literasi tentang e-business (keunggulan dan dampak negatifnya) bagi masyarakat;

Setelah menemukan fenomena mitra pada saat survei maka kami membuat media sosialisasi berupa buku sosialisasi dengan bahasa sederhana yang mudah dipahami beserta gambar-gambar pendukung yang kami harapkan akan mempermudah mitra memahami apa itu e-business dan apa dampak positif ketika kita berbisnis secara online.(Wahyuni \& Turisno, 2019)

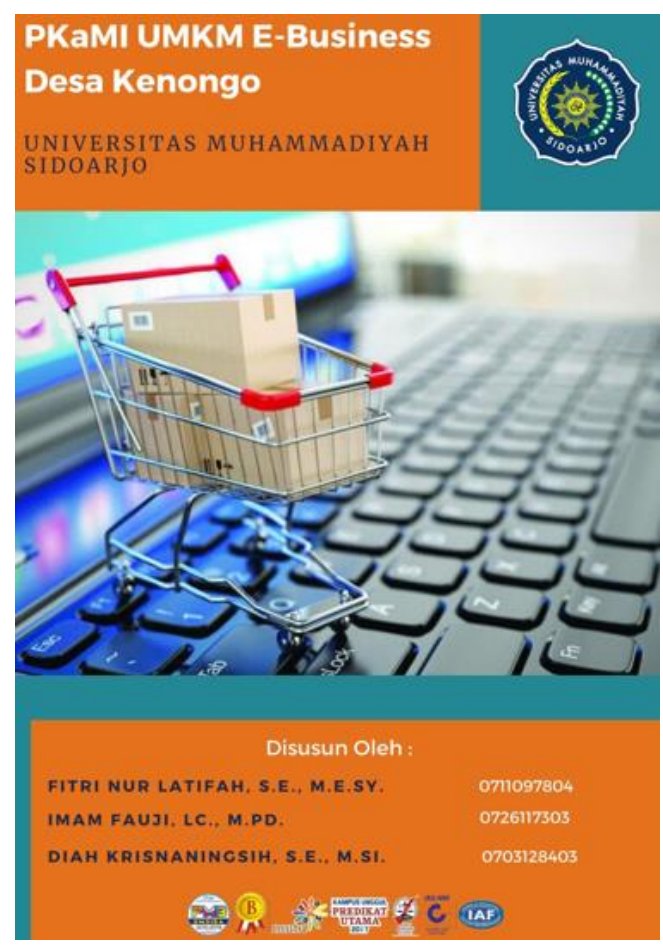

Gambar 1. Tampilan buku pelatihan e-business 
Buku ini kami buat dengan menampilkan gambar-gambar dan bahasa yang sederhana sehingga mudah dipahami. Juga ditambahkan pengalaman-pengalaman oarang yang bernah melakukan transkasi dan tipstips menghindari penipuan yang terjadi pada e-business.

4) Sosialisasi dan literasi tentang e-business (keunggulan dan dampak negatifnya) bagi masyarakat.

Pada tahapan sosialisasi ini kami melibatkan mahasiswa prodi perbankan syariah Fakultas Agama Islam Universitas Muhammadiyah Sidoarjo dalam menyampaikan sosialisasi kepada pihak mitra tentang apa itu $e$-business dan dampaknya pada masyarakat.

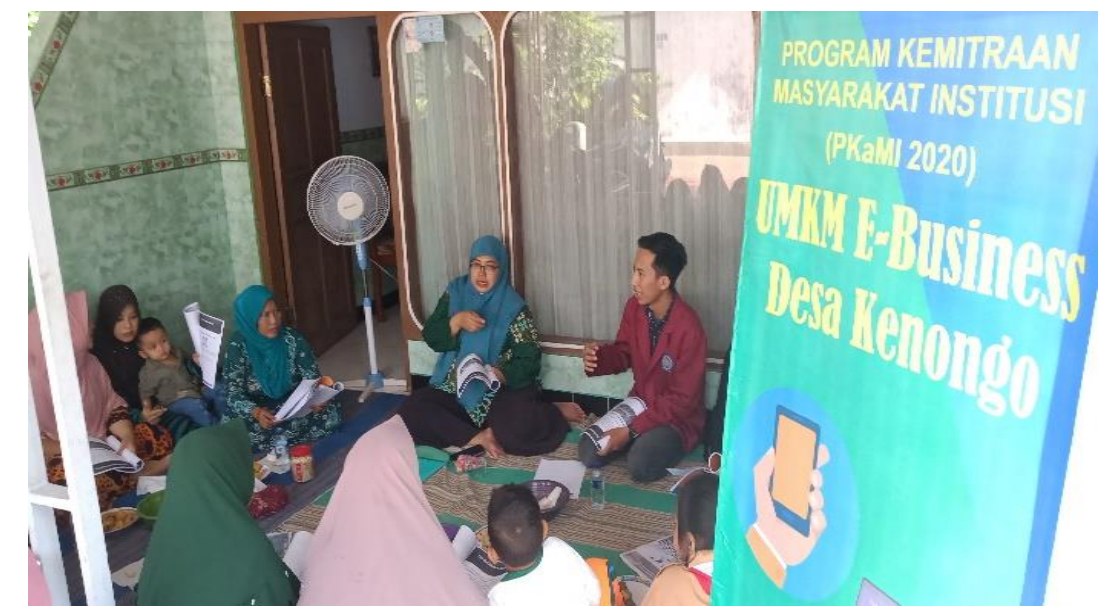

Gambar 2. Kegiatan sosialisasi dan pelatihan kepada mitra

Kegiatan ini dilakukan sesuai kesepakatan dengan mitra untuk hari dan jam kegiatan, dikarenakan mitra juga ada kegiatan berdagang maupun menunggu anaknya di sekolah. Saat mengikuti acara sosialisasi dan pelatihan para ibu rumah tangga tersebut sangat antusias dan banyak bertanya tentang materi yang kami tanyakan untuk lebih memperjelas apa yang ingin mereka ketahui.

Seperti menanyakan bagaimana menentukan sebuah pesan di SMS atau WhatsApp bukan merupakan penipuan atau menganalisa pesan-pesan 
tersebut apakah penipuan atau benar adanya. Bertanya tentang pinjol yang banyak sekali pemberitaan negatif tentang hal tersebut dan masih banyak lagi diskusi yang terjadi dalam acara tersebut.

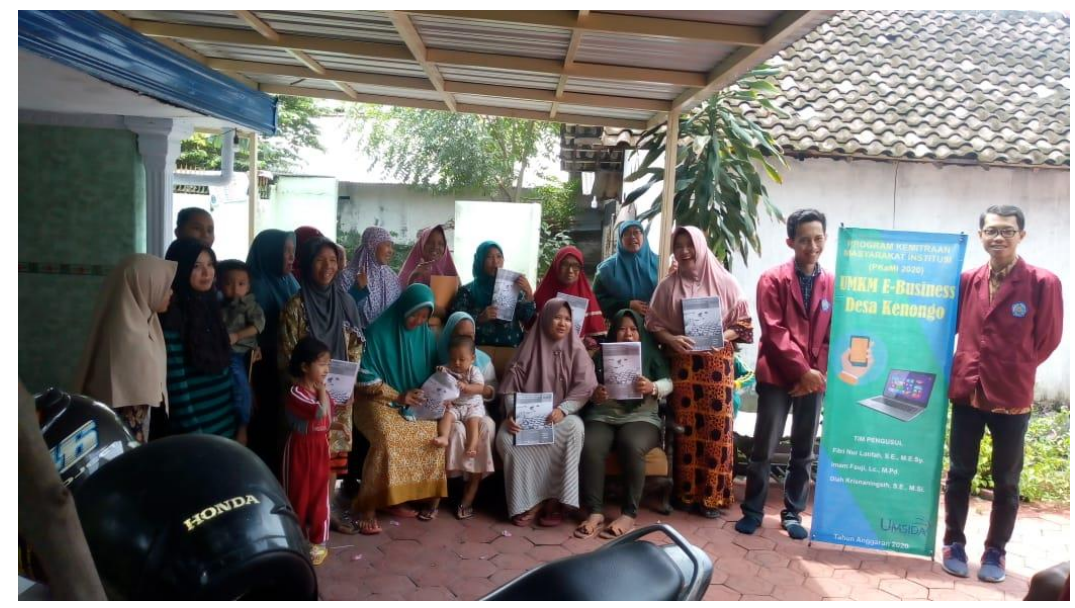

Gambar 3. Kegiatan sosialisasi dan pelatihan kepada mitra

Di dalam setiap kegiatan baik dalam proses survei, pembuatan media sosialisasi dan literasi serta kegiatan sosialisasi itu sendiri keterlibatan mitra bukan hanya pada aspek pelaksanaan, tetapi mulai dari komunikasi masalah, perencanaan program serta pelaksanaan, sehingga ketercapaian target luaran dan kesinambungan program terjamin.

Evaluasi program akan dilakukan pasca kegiatan PKaMI dilaksanakan dengan berupa visitasi mitra untuk memantau pemahaman mitra akan $e$ business yang sudah ada baik itu berupa fintech, pinjaman online, jual beli online baik yang konvensional dan syariah serta bagaimana mitra bisa menilai apakah e-business tersebut aman atau tidak untuk dilakukan.

\section{Hasil dan Diskusi}

Desa Kenongo adalah desa yang berkembang terus ekonominya dibuktikan dengan makin banyaknya jenis usaha baru yang terus bermunculan, hal ini tentu membutuhkan pembinaan maupun pendampingan agar usaha tersebut bisa maju 
162 | Pendampingan Masyarakat Desa Kenongo dalam Peningkatan E-Business ...

dan berkembang.(Latifah, Maika, \& Kumalasari, 2018)

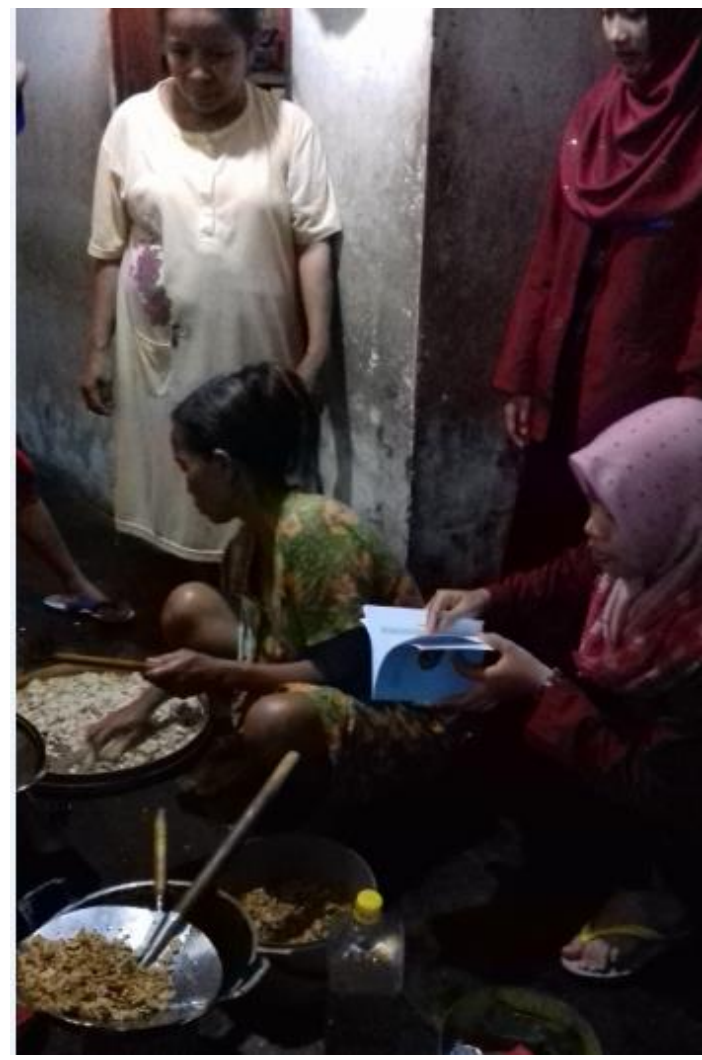

Gambar 4. Kegiatan pendampingan kepada mitra

Hasil program pengabdian pada masyarakat ini adalah adanya transfer knowladge keadaan mitra tentang apa itu e-business. Sehingga tingkat literasi mitra pada $e$-business bisa meningkat serta bisa mengaplikasikannya dalam kehidupan sehari-hari dan semoga mitra bisa masuk kedalamnya serta meningkatkan pangsa pasar usaha mitra itu sendiri.

Pada tahapan awal tim kami merumuskan bersama bagimana kondisi mitra yang sesungguhnya dengan melakukan sosialisasi kepada para ibu rumah tangga di desa Kenongo, sebagian besar memang belum begitu memahami tentang $e$ business itu sendiri dan takut untuk mengaplikasikannya dalam kehidupan seharihari. 
Fitri Nur Latifah, Imam Fauji, Diah Krisnaningsih | 163

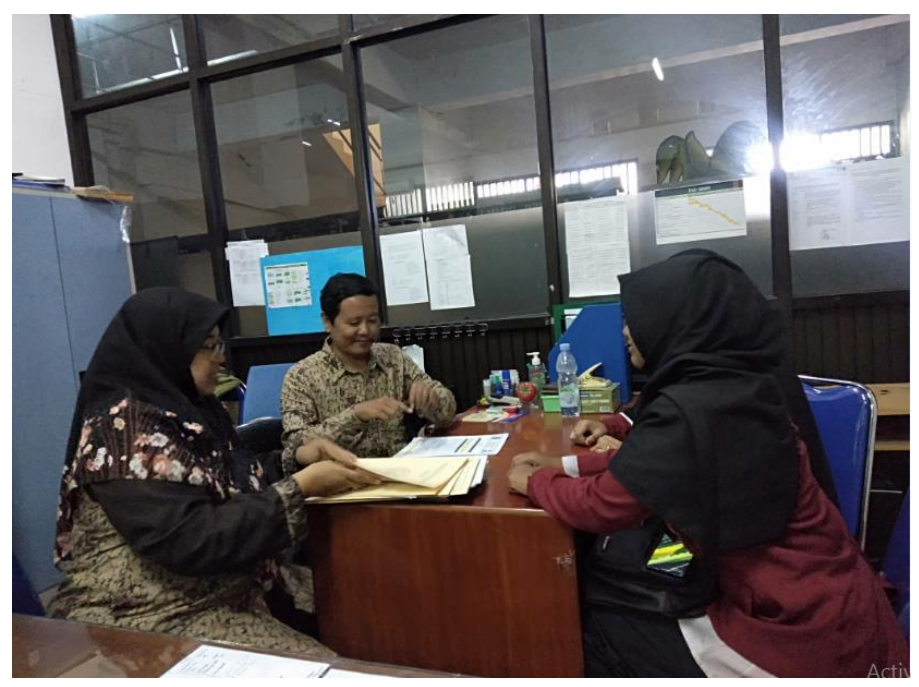

Gambar 5. Kegiatan persiapan PkaMI e-business

Pada tahap awal kami menganalisa kebutuhan mitra seperti apa dalam rangka peningkatan literasi terhadap e-business itu sendiri. Program yang sederhana namun efektif adalah dengan cara sosialisasi dan pelatihan akirnya kami pilih dalam kegiatan ini. Kami kemudian menyiapkan bahan-bahan maupun materi sosialisasi dan pelatihan untuk mitra.

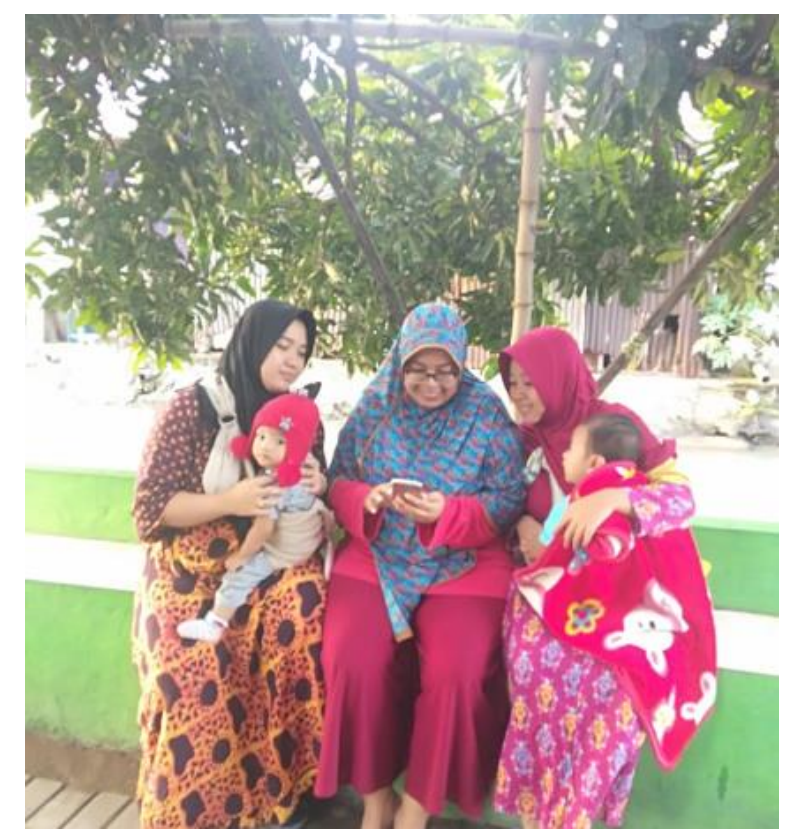

Gambar 6. Kegiatan sosialisasi kepada mitra 
164 | Pendampingan Masyarakat Desa Kenongo dalam Peningkatan E-Business ...

Dari kegiatan ini dampak positif yang sudah bisa dilihat adalah mitra menjadi lebih paham tentang pengaruh teknologi dalam kegiatan ekonomi dan usaha. Dengan peningkatan tingkat pemahaman mitra terhadap e-business akan menjadikan mereka lebih berhati-hati dan waspada terhadap setiap tawaran dan kegiatan yang berhubungan dengan e-business serta mampu memanfaatkan peluang-peluang yang ada yang ditawarkan pada e-business seperti peminjaman peer to peer yang syaratnya tentu tidak sedetail persyaratan pengajuan kredit ke Bank.(Siharis, 2019)

\section{Kesimpulan}

Pendampingan masyarakat dalam peningkatan e-business di Desa Kenongo menjadi salah satu alternatif dalam meningkatkan usaha mandiri mitra. Pemahaman mitra terhadap e-business menajdi menningkat sehingga menjadikan mereka lebih berhati-hati dan waspada terhadap setiap tawaran dan kegiatan yang berhubungan dengan e-business serta mampu memanfaatkan peluang-peluang yang ada yang ditawarkan pada e-business

\section{Ucapan Terma Kasih}

Ucapan terimakasih atas terlaksananya kegiatan pengabdian ini disampaikan kepada Universitas Muhammadiyah Sidoarjo melalui DRPM yang telah memberikan bantuan hibah pengabdian PKaMI UMKM, Dekan Fakultas Agama Islam Universtas Muhammadiyah Sidoarjo yang telah memberikan persetujuan dan motivasi dalam terlaksananya kegiatan ini, serta masyarakat Desa Kenongo selaku mitra kegiatan pegabdian ini. 


\section{Daftar Pustaka}

Latifah, F. N., Maika, M. R., \& Ariyanti, N. (2019). PKM Geo UMKM Desa Kenongo. 3(3), 259-266.

Latifah, F. N., Maika, M. R., \& Kumalasari, H. M. (2018). Manajemen Bisnis Ibu Rumah Tangga yang Bankable di Desa Kenongo. 2, 139-144.

Latifah, F. N., Maika, M. R., \& Masruchin, M. (2017). Pembukuan dalam Perspektif Islam Studi Kasus Pembukuan Bagi Wirausaha Pemula Ibu Rumah Tangga Desa Kenongo. Perisai : Islamic Banking and Finance Journal, 1(2), 117.

Maika, M. R., \& Kautsar, I. A. (2019). Hiijrah: Islamic E-Commerce Disurpted Strategy. Economica: Jurnal Ekonomi Islam, 10(1), 57-86.

Perdani, G., Waziiroh, E., Deoranto, P., Perdani, C. G., \& Waziiroh, E. (2019). Pengembangan Paket Kuliner Lokal Desa Ngadas Untuk Mendukung Wisata Taman Nasional Bromo Tengger Semeru (TNBTS). 2(November).

Siharis, B. R. I. K. (2019). Pengaruh Financial Technology (Fintech) Terhadap Perkembangan UMKM DI Kota Magelang. Jurnal Prosiding Seminar Nasional Dan Call For Papers, 347-356.

Wahyuni, R. A. E., \& Turisno, B. E. (2019). Praktik Finansial Teknologi Ilegal Dalam Bentuk Pinjaman Online Ditinjau Dari Etika Bisnis. Jurnal Pembangunan Hukum Indonesia, 1(3), 379.

Wardhana, B., Mukminin, M. A., Syafira, I., Isnawati, R., \& Latifah, F. N. (2020). Wo men's empowering through sharia crowdfunding. 05(01), 15-20. 
166 | Pendampingan Masyarakat Desa Kenongo dalam Peningkatan E-Business ... 